\title{
La creación de la Real Junta del Almirantazgo (1624-1628)
}

\author{
Francisco javier diaz González *
}

\begin{abstract}
RESUMEN
ABSTRACT

La Junta del Almirantazgo fue una institución creada por Felipe $N$ con la misión de combatir el contrabando holandés en la Península lbérica. Su origen se encuentra en el Almirantazgo de Sevilla de 1624, una asociación de comerciantes flamencos y alemanes residentes en dicha ciudad, cuya misión era terminar con el poderío comercial holandés. Para ello disponía de una flota de 24 navios, encargados de escoltar a los navios mercantes del Almirantazgo y de una serie de agentes situados en los puertos de Andalucia encargados de apresar barcos, mercancias o comerciantes de Holanda o cómplices de éstos. La falta de flota hizo que el Almirantazgo de Sevilla entrase en decadencia y que la Junta del Almirantazgo, tribunal de apelación, asumiera las funciones del Almirantazgo de Sevilla a partir de 1628. La Junta del Almirantazgo desarrolló sus

Junta del Almirantazgo was a created institution by Felipe IV with the mission of combatting the dutch contraband in Iberian Peninsula. The origin was found in Almirantazgo de Sevilla of 1624, an association of flamenco merchants an resident germans in tells city. Whose mission was to finish with the commercial dutch power. For it was disposing of a fleet of 24 boats, entrusted escorting to the merchants of the Almirantazgo and a series of situated agents in the ports of Andalucia entrusted capturing boats, merchandises or merchants of Holland or accomplices of these. The lack of fleet did that Almirantazgo de Sevilla entering in decadence and that Junta del Almirantazgo, appellate tribunal, might assume the functions of the Almirantazgo de Sevilla to part of 1628. Junta del Almirantazgo
\end{abstract}

* Universidad de Alcalá de Henares. 
competencias en toda la Península

Ibérica gracias a los Veedores del Comercio y del Contrabando, situados en los principales puertos $y$ encargados de vigilar los navios y comerciantes extranjeros. developped the competitions in all Peninsula Iberian thank you Veedores del Comercio y del Contrabando, situated in the port and entrusted principals watching the boats and foreign merchants.

En 1625 se creó la Real Junta del Almirantazgo, órgano encargado de combatir el contrabando holandés en la Península. Hija de la política de Olivares, la Junta desempeñó sus funciones con suma eficacia y brillantez antes de ser disuelta al poco tiempo de caer el valido, en la primavera de 1643. El presente trabajo estudia los origenes y la creación de la Junta hasta su trascendental modificación por la Real Cédula de 16 de mayo de1628.

\section{EL ALMIRANTAZGO DE SEVILLA}

A. La «nación» flamenca de Sevilla durante la Tregua de los Doce Años

Durante marzo y abril de 1624, Felipe IV y el conde duque de Olivares realizaron una visita por Andalucía. En Sevilla recibieron el homenaje de las principales corporaciones mercantiles de la ciudad, y entre ellas la de la «nación» flamenca, que fue recibida en audiencia el 9 de marzo. La representación flamenca, encabezada por sus dos cónsules, expuso al monarca sus quejas por la crítica situación que atravesaba, pues el bloqueo comercial impuesto a los holandeses al término de la Tregua de Amberes (9-4-1609) había supuesto para ellos un duro golpe económico y, además, se veían sujetos a infinitos acosos y vejaciones por parte de los oficiales reales encargados de perseguir el embargo ${ }^{1}$. Junto a las quejas, también expusieron al monarca cuál seria la solución adecuada para acabar con esa terrible situación y ese remedio, a decir de Domínguez Ortíz, sería el Almirantazgo de Sevilla ${ }^{2}$.

Después de la firma de la Tregua de Amberes, aunque se había abierto el comercio de la Península a los holandeses por un plazo de doce

\footnotetext{
Elliott, J.H., El Conde-Duque de Olivares. El politico en una época de decadencia, 6. ed., Barcelona, 1991, pág.. 168.

2 Dominguez Ortiz, A., “El Almirantazgo de los Paises Septentrionales y la política económica de Felipe IV", Hispania, 8 (1947), pág. 274.
} 
años, los súbditos de las Provincias Obedientes de Flandes sufrían vejaciones por parte de las autoridades españolas. Felipe III promulgó una Real Cédula el 15 de mayo de $1610^{3}$ estableciendo una serie de limitaciones a los oficiales municipales y reales con el propósito de salvaguardar el comercio entre España y los demás Estados europeos, especialmente con las Provincias Obedientes de Flandes.

La mayor parte de estos comerciantes flamencos procedían de Amberes, como los Smidt, los Janssen de Bisthoven, los Helman, los Canis, los Cobert, los Schenaerts, los de Coninck (o Conique), los Verhoeven o Beruben, los De Haze, los De Meulenaere. De los alrededores de Amberes procedían los Antonio, los Nicolás, los De Neve y los Vander Linden. Pero también otras ciudades flamencas estaban representadas, como Lille, de donde procedian los De la Rulle y los De Fourmestraux; Brujas, los Jácome, los Florido, los Giles, y los descendientes de la antigua colonia española que eran considerados como flamencos, como los Peralta, los Aranda, los Melgar, los Cúllar y los Espinosa; de Gante, los Codde y los Lopens; de los territorios valones y la parte meridional de Brabante, los Vivien, los De Vendeuille, los Plamont y los Sirman ${ }^{4}$.

Los flamencos rápidamente adoptaron las costumbres de la sociedad española. La colonia flamenca sevillana no se aisló en un barrio como otras, sino que se instalaron por toda la ciudad y se unieron mediante matrimonio con importantes familias sevillanas ${ }^{5}$.

En el plano religioso, los flamencos mantenian desde antiguo su cofradía dedicada a san Andrés, contribuyendo para su mantenimiento con una tasa especial sobre el comercio que subió de 1 por 1000 en 1604 al 3 por 1000 en $1619^{6}$. La cofradía estaba gobernada por dos mayordomos, elegidos por un mandato de dos años. A través de esta cofradía, los flamencos crearían en Sevilla un Consulado de Comercio.

Por medio de fray Enrique Conde, maestro de la orden de predicadores, los comerciantes flamencos, junto con los alemanes, solicitaron a Felipe III que los dos mayordomos de la cofradía de san Andrés, tanto los actuales, que eran Nicolás Antonio y Roberto Barcelés, como los futuros,

DE LA CONCHA, I, "El Almirantazgo de Sevilla. Notas para el estudio de las instituciones mercantiles en la Edad Moderna", Anuario de Historia del Derecho Español, XIX (1948-1949), pág. 469-470.

STOLS, E., "La colonia flamenca de Sevilla y el comercio de los Países Bajos en la primera mitad del siglo xVII', Anuario de Historia Económica y Social, 2 (1969), pág. 366.

5 Dominguez Ortiz, A., Orto y ocaso de Sevilla, $3{ }^{a}$ ed., Sevilla, 1981, pág. 77.

6 Stols, E., op. cit., pág. 368 
fuesen nombrados Cónsules encargados de la inspección del comercio que practicaban los componentes de esta cofradía. Felipe III aceptó la sugerencia presentada por fray Enrique Conde y por Real Cédula de 10 de junio de 1615, creó el Consulado de la «nación» flamenca y alemana, con la condición de que los nombramientos de los Cónsules serían aprobados previamente por el monarca ${ }^{7}$. Dos años más tarde, por Real Cédula de 20 de octubre, el rey establece las competencias de los cónsules, teniendo los mismos honores y preeminencias que los que tenían el prior y cónsules de los Consulados de Sevilla, Lisboa, Barcelona, Burgos, Bilbao y de otras ciudades de los dominios del rey de España. Conocerian de todos aquellos pleitos de carácter mercantil que se produjeran entre los miembros del Consulado. Tenían derecho a fletar y cargar todos los navíos que salieran de Sevilla para el norte de Europa y despachar la entrada y salida de "los sus maestres y capitanes y todas las demás cosas, y requisitos a ellos concernientes"; examinar los poderes y compañias que las "naciones" flamenca y alemana realizaran; y, por último, llevarían la tarifa de una blanca al millar de todas las mercancías que negociasen y despachasen tanto a la entrada como a la salida de Sevilla y de su distrito ${ }^{8}$.

La creación de un Consulado propio para los comerciantes flamencos tenía como objetivo potenciar el deficitario comercio existente entre los Países Bajos obedientes y la Península, es decir, resucitar el antiguo comercio que existía entre Castilla y Flandes en épocas bajomedievales. Pero no se alcanzaron las esperanzas que se depositaron en la creación del Consulado, pues no fue suficiente para arrebatar a los holandeses el papel de intermediarios entre Flandes y España.

A los ocho años de creación del Consulado flamenco se produjo la visita de Felipe IV y Olivares a Sevilla. Olivares confiaba en su plan de crear compañias de comercio, tal como habia escrito en su memorial presentado a Felipe IV, para incrementar el tráfico mercantil entre la Península y Flandes. La petición de los flamencos hecha al rey coincidía con los planes de Olivares y así, por Real Cédula de 4 de octubre de 1624 se creó "un Consulado, y Compañía, con título de Almirantazgo de los Comercios de los Países obedientes de Flandes, y Provincias Septentrionales con la Provincia del Andalucía, y Reyno de Granada»?

De la Concha, I., op. cit., pág. 470-472.

Idem., pág. 473-474.

9 ABReu BeRtodANo, J.A., Colección de Tratados de paz, alianza, neutralidad..., reglamento de limites, comercio, navegación, etc., hechos por los pueblos..., reyes y príncipes de España con los pueblos, reyes... y demás potencias de Europa y otras partes del Mundo... desde antes del establecimiento de la monarchía gothica. Vol. III. Madrid, 1742, pág. 437-448. 


\section{B. La Real Cédula de 4 de octubre de 1624}

\section{Los órganos rectores de la institución}

Dos serían los órganos directores del Almirantazgo: la Junta de Sevilla, a la que, para evitar confusiones, llamaremos Almirantazgo de Sevilla, y el Consejo o Tribunal que se crearia en la Corte, la futura Junta del Almirantazgo.

Para cumplir con eficacia su cometido, se ordenaba a las otras instituciones de Castilla que colaboraran estrechamente con el Almirantazgo de Sevilla, especialmente los Capitanes Generales de las armadas y galeras y con el Administrador de los Almojarifazgos Mayor y de Indias ${ }^{10}$.

\section{El Almirantazgo de Sevilla}

El Almirantazgo de Sevilla estaría formado por siete personas elegidas por los mercaderes que se asociaran. Tenian que tener una serie de cualidades que garantizasen el buen funcionamiento y gobierno de la institución: expertos en el comercio con Europa, hacienda suficiente y residencia en España ${ }^{11}$.

Los miembros del Almirantazgo de Sevilla gozaban de una serie de privilegios. Uno de ellos era el perdón general y absoluto de todo tipo de delitos de contrabando que hubieran cometido hasta ese momento y de los que se le imputasen en el desempeño de su misión en el Almirantazgo ${ }^{12}$. También tenían derechos sobre las mercancías confiscadas y otros sobre los gastos que se realizasen para la construcción y mantenimiento de la flota ${ }^{13}$. Por último, y aquí se incluyen los oficiales subalternos del Almirantazgo, todo aquél que sirviera durante cinco años en esta institución, y hubiera creado un hogar en España, podría conseguir carta de naturaleza ${ }^{14}$.

Al lado de estas siete personas que habrían de dirigir el Almirantazgo sevillano, Felipe IV otorgaba a estos dirigentes la facultad de poder nombrar los ministros y oficiales que creyeran necesarios para la buena gestión

\footnotetext{
Caps. 27 y 28 .

Cap. 1

Caps. 26.

Caps. 29.

Caps. 30 .
} 
y administración de la institución ${ }^{15}$. Más importancia tiene aún la figura del Asesor Letrado. Su misión era aconsejar a los siete dirigentes del Almirantazgo a la hora de tomar decisiones en el ámbito jurisdiccional, como lo tenía el Consulado de Sevilla ${ }^{16}$.

A los siete dirigentes del Almirantazgo de Sevilla, al Asesor Letrado y al personal subalterno que se nombrase, se les designaría un salario conveniente ${ }^{17}$, salario que provendría de los ingresos obtenidos por la confiscación de los bienes capturados ${ }^{18}$ y de la tasa del $1 \%$ con que se gravaría a todas las mercancías que entrasen o saliesen de España de los comerciantes flamencos y alemanes pertenecientes al Almirantazgo, ${ }^{19}$, tasa que se cobraría en todas las aduanas del Almojarifazgo Mayor ${ }^{20}$. También se sacaría de los bienes capturados y de la tasa del $1 \%$, todos aquellos gastos extraordinarios que realizasen los miembros del Almirantazgo ${ }^{21}$.

El Almirantazgo de Sevilla desempeñaría su cometido en un cuarto "alto y bajo» de la Lonja de la ciudad, en el mismo edificio donde residían el Prior y los Cónsules del Consulado de Cargadores y los asentistas de la avería $^{22}$.

2. Funciones y competencias del Almirantazgo de Sevilla.

a) De administración y gobierno. Los miembros del Almirantazgo de Sevilla podían tener sus agentes en los puertos holandeses y de otras potencias enemigas de España, para conocer de esta manera las formas y los modos que se usaban para introducir mercancias de contrabando en el territorio sujeto a su jurisdicción, las costas andaluzas y el reino de Granada $^{23}$.

Pero la más importante era la inspección que podían realizar a los navíos que entraban y salían en los puertos andaluces procedentes o con destino al Septentrión. La visita era realizada por comisarios nombrados

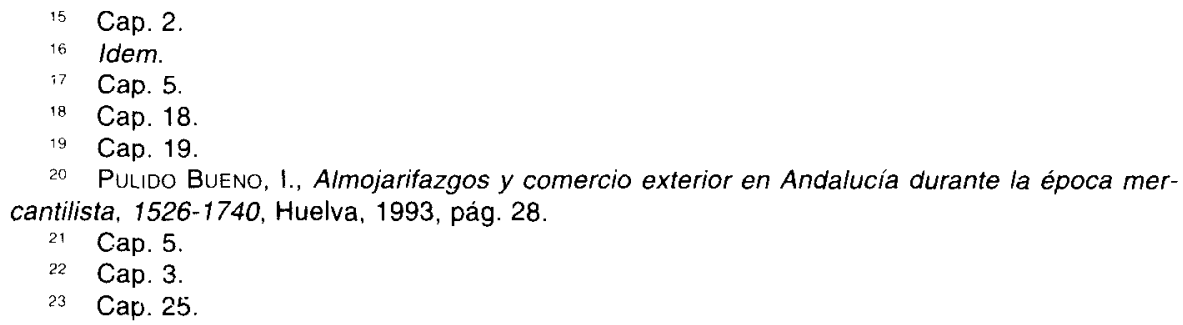


por el propio Almirantazgo de Sevilla, requiriendo al Corregidor del lugar o a otra autoridad que les acompañase; en el caso que el Corregidor o la autoridad requerida no asistiese sin causa justificada, el comisario del Almirantazgo, con auto del escribano del lugar, realizaria la visita y daría cuenta de ese hecho. El Almirantazgo, a su vez, informaría al monarca, el cual decidiría con respecto a la autoridad lo que considerase conveniente.

Comenzada la visita, y con ella la causa de contrabando si se encontrase algo, ninguna otra autoridad diferente al Almirantazgo podría interferir en el desarrollo ulterior, y en caso de que el comisario actuara en exceso de sus funciones, se daría cuenta de ello al Consejo o Tribunal que se crearia en la Corte, la futura Junta del Almirantazgo ${ }^{24}$.

¿Cuál era el objeto de la visita? Encontrar bienes y mercancías procedentes de las Provincias Unidas. La Real Cédula de 4 de octubre de 1624 reitera la prohibición de entrada en Andalucía y en el Reino de Granada de mercancias holandesas considerándolas perdidas, así como las de otra procedencia que vinieren con ellas ${ }^{25}$, y todo tipo de mercancias que están prohibidas sacar del Reino; es decir, los bienes de contrabando, que de una lectura de la Real Cédula de 4 de octubre de 1624, eran las siguientes:

- Navíos, bienes y manufacturas que perteneciesen a los rebeldes o a sus aliados ${ }^{26}$.

- Bienes pertenecientes a terceras personas, pero procedentes de los Estados rebeldes ${ }^{27}$.

- Metales preciosos, moneda, perlas, joyas y todas aquellas mercancias y productos que necesiten licencia para su salida ${ }^{28}$.

- Mercancías producidas en China o en las Indias Orientales y traídas a la Península desde el Norte de Europa o directamente desde sus zonas de producción, sin que conste en este último caso prueba que han sido inspeccionadas por las autoridades portuguesas ${ }^{29}$.

Otra de las funciones administrativas del Almirantazgo de Sevilla era el control del comercio con el Septentrión. Para ello ordenaban a todos los comerciantes que negociaban con el Norte de Europa residentes en Andalucia,

\footnotetext{
Cap. 17.

Cap. 21

Cap. 18.

ldem.

ldem.

Cap. 22
} 
tanto naturales como extranjeros, que acudieran en persona o por medio de representantes a los llamamientos del Almirantazgo y obedecer sus órdenes, y en caso de incumplir estos mandamientos del Almirantazgo, podían ser castigados con las penas que se creyera conveniente, así como en el caso de que el Almirantazgo les encargara realizar ciertos negocios y tratos, y ellos no los cumplieran sin justificar su desobediencia ${ }^{30}$.

El Almirantazgo de Sevilla estaba también encargado de recibir las fianzas de los mercaderes que comerciaban con el Septentrión, fianza que garantizaba que esas mercaderías no irían a parar a manos de los rebeldes ${ }^{31}$.

Por último, podrian dar todo tipo de Ordenanzas e Instrucciones que creyesen conveniente para la buena marcha de la institución, tanto para su buen gobierno y administración, desarrollo comercial, y también para el cumplimiento de sus decisiones judiciales, siempre y cuando sean confirmadas previamente por el monarca ${ }^{32}$.

b) De tipo jurisdiccional. El Almirantazgo de Sevilla tenía competencia judicial civil y criminal para conocer de aquellos casos que la Real Cédula de 4 de octubre de 1624 le otorgaba ${ }^{33}$, utilizando esa competencia de igual forma que la Casa de la Contratación de las Indias. Previéndose que los siete dirigentes del Almirantazgo no eran expertos en Derecho, se creó, como ya hemos apuntado, el puesto de Asesor Letrado, que ayudaría a sustanciar y sentenciar las causas que llegaran a esta institución ${ }^{34}$.

La función principal del Almirantazgo de Sevilla en materia judicial era conocer en primera instancia de todas aquellas causas de contrabando que arriba hemos señalado, inhibiendo a los demás Jueces y Tribunales de Castilla de su conocimiento ${ }^{35}$. Es más, el conocimiento de las causas de contrabando sería exclusivo y excluyente del Almirantazgo de Sevilla, pues si alguna otra Justicia o Tribunal conociese de alguna de esas causas, debería inmediatamente inhibirse y enviar las actuaciones al Almirantazgo sevillano ${ }^{36}$. Sin embargo, en la práctica, la mayor parte de las veces no ocurrió así y fueron muy frecuentes los conflictos de competencias.

El Almirantazgo de Sevilla estaba configurado también como una asociación de mercaderes, al modo de los Consulados de Comercio existentes

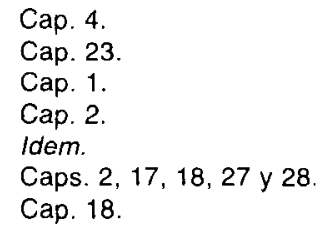


en esa época, por lo cual también podía conocer de todos aquellos pleitos mercantiles que tuvieran los comerciantes asociados a él.

De las sentencias, autos y demás resoluciones judiciales dictadas por el Almirantazgo de Sevilla, conocería en grado de apelación el Consejo o Tribunal que se crearía en la Corte, inhibiendo de su conocimiento a los demás tribunales de Castilla ${ }^{37}$.

En cuanto al procedimiento judicial a seguir, la Real Cédula de 4 de octubre de 1624 no lo aclara, sólo dice que en los bienes confiscados, dada la primera sentencia, si es condenatoria y si consienten sus propietarios, podrán ser vendidos en subasta pública, pero si el Tribunal o Consejo de la Corte revocase en todo o en parte la decisión apelada, se entregara al propietario de los bienes el dinero producido de la venta, después de descontar las costas ${ }^{38}$.

\section{El Tribunal o Consejo de la Corte}

El capítulo $2 .^{\circ}$ de la Real Cédula de 4 de octubre de 1624 prevé la creación en la Corte de un Tribunal o Consejo que conocería en grado de apelación de las decisiones judiciales tomadas por el Almirantazgo de Sevilla, siendo sus miembros directamente nombrados por el rey. En cuanto al sustento de los consejeros que debían formar parte de ese Tribunal, éste provendria de las presas y de la tasa del $1 \%$.

\section{La flota}

Para mantener el comercio entre Andalucía y el Septentrión y combatir a los holandeses, la Real Cédula de 4 de octubre de 1624 prescribe que el Almirantazgo de Sevilla estaba obligado a formar en el plazo de dos años una flota de veinticuatro navíos de guerra ${ }^{39}$, número que podía ser aumentado por los que se capturasen, siempre y cuando se demostrase que habian sido fabricados en astilleros holandeses; pero también podian ser vendidos los navios capturados a particulares, con la condición que no sean usados para comerciar con los rebeldes o con comerciantes que trafican con ellos ${ }^{40}$.

Caps. 27 y 28.

Cap. 24.

Cap. 6.

Cap. 12. 
La flota estaría al mando de un almirante, un vicealmirante y por otros oficiales que se considerase necesario. Para ello el Almirantazgo debía presentar una terna de personas para gobernar la flota y si todos o alguno de ellos residiese en Flandes, deberían ser aprobados por la Infanta Isabel Clara Eugenia, Gobernadora General de Flandes. En el caso que fueran de otros territorios bajo soberanía del rey de España, deberían ser aprobados por las autoridades superiores de esos territorios. Excepto en el caso de los alemanes, no podian ser designados extranjeros para mandar la flota, salvo si el propio Felipe IV otorgase dispensa, con el consentimiento del Almirantazgo de Sevilla ${ }^{41}$.

En lo referente a las tripulaciones, De la Concha dice que se concedia al Almirantazgo toda clase de facilidades para el enrolamiento de las dotaciones de los navíos, exigiéndose como únicos requisitos que fuesen católicos y que no viviesen en los Estados rebeldes, especificando claramente que aunque fueran naturales de los mismos, bastaba que vivieran fuera de ellos o que estuviesen avecindados en las Provincias obedientes ${ }^{42}$.

La flota que el Almirantazgo debía armar tenía la misión de escoltar y proteger la navegación y el comercio de Andalucía con los Paises Bajos obedientes y con Alemania; es decir, lo que se pretendía era instaurar el sistema de las Flotas de Indias, que hasta ese momento habian dado buenos resultados. El propio Almirantazgo, como la Casa de la Contratación, sería el encargado de dar las órdenes correspondientes a los viajes, entradas y salidas de esa flota, siempre que navegase por cuenta del Almirantazgo ${ }^{43}$.

En cuanto a su provisión y mantenimiento, el Almirantazgo podía comprar lo que necesitase, asistiéndole todas las autoridades en lo que fuese necesario y sin pagar ningún tipo de derecho o tributo en la adquisición de esos bienes, siempre y cuando no los revendiesen o realizasen cualquier otro acto de disposición sobre ellos. Por último, en el caso de sacar dinero al exterior para comprar los bastimentos y pertrechos, el Almirantazgo debía pedir permiso al Consejo de Hacienda o al de Estado, declarando la cantidad y cual era su destino ${ }^{44}$.

Los navíos de la flota del Almirantazgo gozaban de una serie de privilegios. En primer lugar, reconociendo la autoridad y prelación que les corresponden a los naturales, tendrían los navíos del Almirantazgo preferencia para cargar mercancías ${ }^{45}$; si en los puertos en los que los navíos del

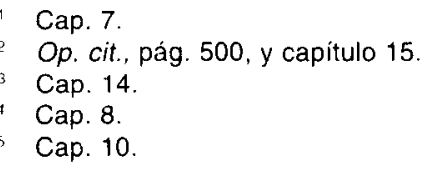


Almirantazgo llegasen hubiera algún buque o buques de las armadas reales, a ellos habrian de someterse, y a ellos estarian sometidos en ruta cuando llevasen el mismo camino todos los demás ${ }^{46}$, aun los que traficaban con América, "que como ellos gozaban de una situación de superioridad" "77; también si el monarca necesitaba de las naves del Almirantazgo para otros cometidos, primero debía concertarlo con esta institución, y si no obtuviese su consentimiento, no podría utilizarlas; y lo mismo sucedía con los pertrechos y municiones para el apresto de la flota ${ }^{48}$.

Junto a su labor de protección y de escolta de las naves que mantienen el comercio de Andalucía con el Septentrión, el otro cometido de la flota del Almirantazgo era combatir a los holandeses y a otros enemigos en el mar y los navios que se capturaran serían juzgados por las mismas leyes y normas que eran utilizadas por los navíos de las armadas reales, reservándose siempre la décima parte a la Hacienda Real ${ }^{49}$.

La flota del Almirantazgo sería financiada con parte de los ingresos de la tasa del $1 \%$ con la que gravaba el Almirantazgo las mercancias que entraban y salian de Andalucía con destino a Flandes, pero sobre todo con las presas que se tomaran en el mar y en los puertos.

El fin que se persiguió al crear la flota del Almirantazgo era

«eliminar la amenaza que los holandeses y franceses hacian pesar sobre nuestro comercio septentrional, y para ello se intentaba aplicar el sistema de flotas que regia, con buen resultado, en el Nuevo Mundo, sin considerar que las circunstancias eran muy distintas, porque después de atender la carrera de Indias y al Mediterráneo, no podíamos mantener en el Mar del Norte otra escuadra, susceptible de derrotar a la holandesa y a la francesa" 50.

\section{LA CREACIÓN DE LA REAL JUNTA DEL ALMIRANTAZGO}

\section{A. La constitución del Almirantazgo de Sevilla}

El 25 de octubre de 1624 Felipe IV promulgaba una Real Cédula en la que se establecian las personas que debian gobernar el Almirantazgo de Sevilla ${ }^{51}$, en contra de lo previsto en el capítulo 1 de la Real Cédula del

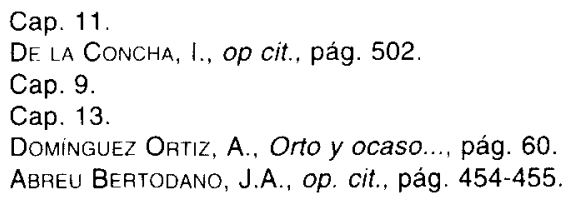


día 4 del mismo mes y año ${ }^{52}$. Con el cargo de Administrador Perpetuo, y como suprema autoridad del Almirantazgo de Sevilla, se nombraba a Fr. Enrique Conde, ya conocido por sus gestiones para crear el Consulado de flamencos y alemanes. Las otras seis personas que ocuparian los otros cargos dirigentes eran Nicolás Antonio, como Veedor; Francisco de Smitt, como Proveedor; Pedro François, como Contador; Guillermo Bécquer; como Pagador; Guillén Clut y Juan Cortés. Sobre éstas dos últimas personas no se determina qué cargo desempeñarian en la organización.

Con la Real Cédula de 25 de octubre se ponía en marcha el plan del Almirantazgo, teniendo como base a los comerciantes flamencos y alemanes residentes en las costas andaluzas. En cuanto a su funcionamiento interno, cosa de la que no se había hablado ni en la Real Cédula de 4 de octubre ni en la del día 25, la Real Cédula de 4 de marzo de 1625 ordenaba que ocupase el primer lugar el Administrador o, en caso de ausencia o impedimento, el "Diputado más antiguo", y siempre en segundo lugar, el Asesor Letrado ${ }^{53}$, mientras que la Real Cédula de 29 de octubre de 1625 , señala la forma en que los miembros del Almirantazgo deben sustanciar los pleitos ${ }^{54}$.

Pero no todos los comerciantes flamencos y alemanes estaban de acuerdo con el plan del Almirantazgo. A finales de 1624, los comerciantes de estas nacionalidades residentes en Málaga redactaron un documento en el que exponian diversos interrogantes que se planteaban en la Cédula fundacional, y que convenia que fueran solucionados ${ }^{55}$. Estas cuestiones se centraban en quién sería el encargado de realizar las instrucciones, tal como se establecía en el capítulo 1; saber cómo eran los privilegios que tenía la Casa de la Contratación, los cuales, conforme al capítulo 2, se habian otorgado al Almirantazgo; aclarar cómo se debía verificar la cantidad justa del abasto y pertrechos que eran necesarios para la flota y también sobre la licencia para poder sacar dinero del reino (capítulo 8); quién seria el encargado de dar las instrucciones sobre la forma de realizar las inspecciones en los navios, como se estipulaba en el capítulo 17; cuándo serían promulgados los edictos de artículos de contrabando (capítulo 21); y, por último, sobre el capítulo 23 señalaban que «debaxo de las penas que pusiere el Rey no se puedan sacar frutos ni mercadurías pareze que será necesario sacar cédulas para que se publique y quándo y cómo".

\footnotetext{
Ver nota 11

De la Concha, I., op. cit, pág. 485.

Biblioteca Nacional de Madrid (B.N.), 3/23124, fols. 39-40.

Pulido Bueno, I., op. cit., pág. 30. El documento en cuestión se encuentra en el Archivo General de Simancas (A.G.S.), Guerra y Marina, leg. 3917.
} 
«Este conjunto de matizaciones - escribe Pulido Bueno- da idea de la minuciosidad y complejidad legal que el proyecto del Almirantazgo de Sevilla llevaba implícito. De forma urgente, se precisaba para desempeñar su cometido, una serie de órdenes que regulasen las misiones que le encomendaba la Cédula fundacional, para delimitar sus funciones y para reunir recursos y medios materiales para el buen desempeño de su cometido" ${ }^{56}$.

También desde el punto de vista de su financiación se detectaron obstáculos. Los mercaderes flamencos y alemanes observaron graves inconvenientes en la principal fuente de recursos del Almirantazgo, la tasa del $1 \%$ sobre las exportaciones e importaciones. Exponian estos comerciantes que al imponerse esta tasa se les causaban graves daños ${ }^{57}$; en primer lugar, que no podían competir con comerciantes de otras nacionalidades exentos de pagar tal tasa; en segundo lugar, aunque muchos tenían la voluntad de participar en la empresa del Almirantazgo, no lo harían por no pagar la tasa del 1\%; por último, que los mismos componentes del Almirantazgo despacharian sus mercancías por medio de comerciantes franceses, ingleses o de otra nacionalidad, para de esa forma no pagar la tasa, realizando con ello un gran perjuicio a la Hacienda Real. Para remediar estos daños, se proponía que la tasa del $1 \%$ se aplicase a todos los comerciantes procedentes del Septentrión que realizaran operaciones comerciales con España, incluidos los franceses y los ingleses.

A todos estos problemas había que añadir el hecho de que los comerciantes flamencos y alemanes debian pagar unos seguros bastante elevados en comparación a los de sus competidores ingleses y franceses ${ }^{58} y$ también corrían el riesgo de sufrir las represalias de los holandeses. Por ello, las casas comerciales de Flandes y Alemania difícilmente accederían a sufragar una institución como el Almirantazgo, porque la fiscalización no habría de parecerles acorde con sus intereses y, por otro lado, se convertirían en el centro de las acciones militares de las demás potencias del norte de Europa ${ }^{59}$.

Felipe IV y Olivares consideraron conveniente extender la institución del Almirantazgo a Flandes. El mismo año de la creación, Gabriel de Roy fue enviado a Bruselas para conseguir el apoyo de los comerciantes y de los representantes provinciales flamencos al plan del Almirantazgo.

\footnotetext{
56 Idem.

57 El documento en cuestión puede encontrarse en A.G.S., Guerra y Marina, leg. 3919.

58 Alcala-Zamora y QueIPo de Llano, J., España, Flandes y el Mar del Norte (1618-1639). La última ofensiva europea de los Austrias madrileños, Barcelona, 1975, pág. 315.

59 Pulioo Bueno, I., op. cit., pág. 32.
} 
Durante dos años Gabriel de Roy estuvo negociando infructuosamente con los comerciantes flamencos, los cuales se sentían irritados por las confiscaciones que el Almirantazgo había efectuado de mercancias presuntamente holandesas, y con los representantes provinciales. Algunas provincias menores aceptaron el plan del Almirantazgo, con la condición de que fuese aceptado por Flandes y Brabante; sin embargo, estas dos provincias votaron en contra ${ }^{60}$. Pero Felipe IV no cedió y el 20 de agosto de 1625 la infanta Isabel Clara Eugenia promulgó un Edicto de su sobrino mediante el cual se ordenaba establecer en Flandes un Almirantazgo semejante al que se habia creado en Sevilla ${ }^{61}$. El Almirantazgo flamenco se estableció en Saint Winoksbergen, cerca de Dunquerque, con el propósito de actuar conjuntamente con el de Sevilla ${ }^{62}$, pero en 1626 se trasladó a Dunquerque. Un Consejo de Comercio, que tendría que trabajar en colaboración con la Junta del Almirantazgo en Madrid, se constituyó en Bruselas en 1627, siendo uno de sus miembros Pieter Roose, uno de los más destacados colaboradores de Olivares ${ }^{63}$. Sin embargo, en 1630, según había informado la infanta Isabel, el Consejo de Comercio todavia no se había constituido y fue enviado el marqués de Leganés a Flandes para agilizar el asunto ${ }^{64}$.

Domínguez Ortiz considera que el devenir de los acontecimientos hizo que el Almirantazgo de Sevilla fuera el aparato administrativo de la institución y el Almirantazgo de Dunquerque la flota ${ }^{65}$, flota que dio lugar a una eficaz organización corsaria bajo marinos capaces como Michael Jacobsen o Jacques Coalert ${ }^{66}$. Pero la institución española y su homóloga flamenca tuvieron vidas distintas y separadas. El Almirantazgo de Sevilla y la Junta del Almirantazgo se dedicaron a combatir el comercio holandés en la forma pasiva de lucha contra el contrabando, mientras que el Almirantazgo de Flandes se constituyó en una eficaz armada de corsarios.

También se intentó vincular al Imperio en el plan del Almirantazgo. Estando visitando Madrid el archiduque Carlos de Austria, Olivares le propuso

60 Isfael, J.I.: “España y los Países Bajos españoles durante la época de Olivares (16211643)", La España del Conde Duque de Olivares, Valladolid, 1990, pág. 122.

${ }^{61}$ DE LA CONCHA, 1.: op. cit., pág. 479-481

62 ISRAel, J.I., The Dutch Republic and the Hispanic World, 1606-1661, Oxford, 1986. pág. 206 (hay traducción española: La República holandesa y el Mundo hispánico, 1606-1661. Madrid, 1997).

63 ISRAEL, J.I., «España...”, pág. 122.

64 Consulta de la Junta del Almirantazgo de 16 de febrero de 1630, en A.G.S., Guerra y Marina, leg. 3155.

65. Dominguez ORTIZ, A., "Guerra económica y comercio extranjero en el reinado de Felipe IV", Hispania, 23 (1962), pág. 80.

66 Stols, E., op. cit., pág. 371 y Strading, R.A.: La Armada de Flandes. Política naval española y guerra europea, 1568-1668, Madrid, 1992, pág. 118-129. 
la empresa y le incitó a tomar su defensa ante la Corte de Viena. Carlos murió en Madrid al poco tiempo de su llegada, y al perder esta oportunidad, el conde duque se dirigió a uno de los miembros del séquito del príncipe, el conde de Schwartzenberg. Según el plan de Olivares, el ejército imperial de Tilly podria tomar la iniciativa expulsando a los holandeses de la Frisia Oriental y ocupar los puertos de Greetsiel y Norden, que servirian de base a los navios del Almirantazgo. Transmitida por el conde de Schwartzenberg la propuesta española, la respuesta del emperador Fernando II no se hizo esperar. El 30 de mayo de 1625 contestaba apoyando el plan de Olivares, pero era España quien debería comenzar las acciones bélicas exigidas por la empresa, pues Felipe IV era el más capacitado para tener a raya a los holandeses. Por último, la participación de la Hansa era esencial para que el plan diese resultado ${ }^{67}$. Sin embargo los acontecimientos posteriores interrumpieron los preparativos. Como consecuencia de la firma en Lyon el 7 de febrero de 1623 de un tratado de alianza entre Francia, Saboya y Venecia para expulsar a los Habsburgo de los territorios de las Ligas Grisonas, en noviembre de 1624 tropas francesas y suizas al mando del marqués de Coeuvres invadieron la Valtelina y en marzo del año siguiente el duque de Saboya invadia los territorios de Génova. En el frente de Flandes, el ejército español estaba inmovilizado sitiando Breda, ciudad que sería conquistada el 2 de junio de 1625.

Aunque los ataques franceses y saboyanos fueron repelidos y se resolvió la crisis italiana tras la firma del Tratado de Monzón de 5 de marzo de $1626^{68}$, la presencia de tropas francesas en el norte de Italia tuvo como consecuencia inmediata que el Imperio no se involucrase en el proyecto del Almirantazgo.

\section{B. La formación de la Junta del Almirantazgo}

Una vez constituido y formado el Almirantazgo de Sevilla, era necesario crear el "Consejo o Tribunal en la Corte", tal como se estipulaba en la Real Cédula de 4 de octubre de 1624. Así lo consideraba el consejero de Hacienda Juan de Pedroso en una carta dirigida a Olivares de fecha de 29 de octubre de $1624{ }^{69}$. En esa carta, Juan de Pedroso recomendaba a Oli-

\footnotetext{
${ }^{67}$ RódenAs VILLAR, R., “Un gran proyecto anti-holandés en tiempo de Felipe IV. La destrucción del comercio rebelde en Europa”. Hispania, 22 (1962), pág. 546 y La política europea de España durante la Guerra de los Treinta Años (1624-1630), Madrid, 1967, pág. 74-75

68 Rodenas VIlar, R., La política..., pág. 68.

69 A.G.S., Guerra y Marina, leg. 3917.
} 
vares que la Junta que se formase en Madrid debería estar compuesta por pocas personas, "porque muchas causan confusión y embarazan los negocios». Insistía en que uno de sus miembros debía ser un jurista, recomendando que fuera o un consejero de Indias o uno de los miembros de la Contaduría Mayor de Hacienda. Los demás miembros de la Junta debían ser consejeros de capa y espada, bastando dos o tres. Seguidamente Pedroso enumeraba a una serie de personas que debían ser miembros de la Junta: Miguel de Ipeñarrieta, Andrés Velázquez y Pedro Mexía. Por último insistía en que sería conveniente que fuera secretario de la Junta Antonio Carnero, uno de los intimos del conde duque, o, en su lugar, el secretario de Estado Pedro de Arce.

Las recomendaciones de Pedroso fueron aceptadas por Olivares en parte. Al poco tiempo de la creación del Almirantazgo de Sevilla se formó una Junta "ad hoc" sobre los medios que podían existir para "restituir a estos Reynos el trato, y comercio, que solía haber con aumento" ${ }^{70}$. La Junta llegó a una serie de conclusiones:

1. Seguir adelante con el proyecto del Almirantazgo para fomentar el comercio con el Septentrión y acabar con la supremacía marítima y comercial holandesa en aquellos lugares.

2. Que se crease cuanto antes el Consejo con sede en la Corte, tal como se ordenaba en la Real Cédula de 4 de octubre de 1624, llamado Junta del Almirantazgo.

3. Que la Junta del Almirantazgo estaría presidida por Fr. Iñigo de Brizuela, obispo de Segovia, presidente del Real y Supremo Consejo de Flandes y Borgoña y antiguo confesor del Archiduque Alberto de Austria. Los otros componentes serían el licenciado Baltasar Gilimón de la Mota, consejero de Castilla; don Diego Mexía, consejero de Guerra y futuro marqués de Leganés; el anteriormente citado Juan de Pedroso, y como secretario de la Junta, Antonio Carnero.

El parecer de la Junta "ad hoc" fue aceptado por Felipe IV y el 8 de enero de 1625 emitió un Real Decreto dirigido al obispo de Segovia para que formara con las personas citadas la Real Junta del Almirantazgo. Por Real Cédula del día 15 de esos mismos mes y año se creaba formalmente la Junta ${ }^{71}$. A la nueva Junta se le otorgaba "poder y jurisdicción en forma, quan plena, y bastante puede darla" para constituirse en Tribunal superior del Almirantazgo de Sevilla.

to Abreu Bertodano, J.A., op. cit., pág. 465.

Idem., pág. 464-467. 
La Real Cédula de 15 de enero de 1625 desarrollaba las competencias judiciales de la Junta del Almirantazgo que estaban establecidas en la de 4 de octubre de 1624. La Junta del Almirantazgo conocería:

1. De los recursos de apelación que ante el Almirantazgo de Sevilla se interpusiesen de todo tipo de pleitos y causas "civiles, y criminales, y mixtas, y las defináis, y determinéis por los autos, y sentencias, que sobre tales causas hubiere lugar darse", revocando o confirmando las decisiones dictadas por el dicho Almirantazgo. De conformidad con lo dispuesto en los capítulos 2 y 27 de la Cédula de 4 de octubre de 1624, reitera la prohibición de recurrir en cualquier forma las decisiones judiciales dictadas por la Junta ante otros Tribunales del Reino.

2. Conocer en vía de suplicación de todas aquellas decisiones que tome referentes al caso, pero que no hayan sido resueltas en la decisión dictada por el Almirantazgo de Sevilla en primera instancia.

3. Previniendo posibles conflictos de competencia entre el Almirantazgo y sus agentes con otras instituciones judiciales y administrativas sobre las visitas que se harian a los navios y presas que se tomaran de mercancías de rebeldes, sería la Junta del Almirantazgo la encargada de resolver tales conflictos; para ello, se le daba poder suficiente para exigir al Almirantazgo de Sevilla y al órgano jurisdiccional en cuestión, que le enviaran todos los informes al respecto para de esa forma pronunciarse. Una vez recibida la información requerida, la Junta determinaría el órgano competente para conocer del asunto, tomando su decisión en forma de auto, que no sería susceptible de ningún tipo de recurso.

En cuanto a la formación y constitución de la Junta, sería suficiente la asistencia de tres de sus miembros y, para cumplir perfectamente su cometido, la Junta del Almirantazgo tenía la facultad de dictar todo tipo de disposiciones, las cuales deberian ser cumplidas como si hubieran sido promulgadas por el Consejo Real de Castilla.

Finalmente, la Real Cédula de 13 de enero de 1625 reitera la competencia privativa de la Junta del Almirantazgo y la inhibición de los otros órganos judiciales castellanos en materia de contrabando.

La Junta del Almirantazgo creada en Madrid será el órgano central de la lucha contra el contrabando durante la etapa de Olivares. «En adelante, - escribe Domínguez Ortiz- cuando se habla del Consejo o Junta del Almirantazgo o de la Junta del Contrabando hay que entender por tal una institución centralizada en Madrid, con agentes en toda la Península, para 
vigilar y reprimir el comercio con los enemigos de la Monarquia; por supuesto, sin medios bélicos de ninguna clase" ${ }^{72}$.

El 10 de febrero de 1625 se envió un Real Decreto a Andrés de Prada, secretario de la Junta de Comercio ${ }^{73}$. En él se ordenaba que se remitiera a la nueva Junta del Almirantazgo "todo lo tocante a las mercadurías de holandeses que entran de contrabando en estos Reynos" y, que enviara Andrés de Prada a Antonio Carnero todos los papeles referentes a esta cuestión. El 27 de dicho mes Antonio Carnero escribía a Andrés de Prada que todavía no había recibido los informes que se habian solicitado, especialmente tres ${ }^{74}$ :

1. Sobre las distinciones de las mercancías que se fabricaban en Holanda y las traídas por los holandeses de Alemania, problema que había sido tratado en una Junta extraordinaria formada por el Presidente del Consejo de Indias, por Juan de Pedroso, por Hortuño de Urizar y Gabriel de Roy.

2. El informe realizado por Juan de Pedroso sobre las formas de evitar la entrada de mercancías holandeses en España, tanto en los puertos marítimos como en los puertos secos.

3. Un informe que trataba sobre las distinciones que se debian hacer a las mercancias realizadas en las Provincias obedientes para diferenciarlas de las de Holanda.

\section{LA FORMACIÓN DE LOS ÓRGANOS INSPECTORES DEL ALMIRANTAZGO. SU DEPENDENCIA JURIDICA DE LA JUNTA DEL ALMIRANTAZGO DE MADRID}

La maquinaria administrativa del Almirantazgo creció rápidamente en menos de dos años. A primeros de 1626 el Almirantazgo había distribuido en las costas andaluzas los siguientes agentes ${ }^{75}$ :

- Sevilla: El administrador, seis jueces, el visitador de los navíos, el fiscal, el secretario, el oficial de los libros mayores, dos alguaciles y un portero.

- Gibraltar: Un factor.

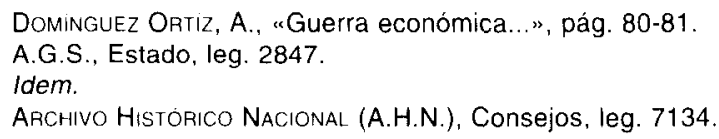


- Málaga: Un factor, un asesor, un escribano, un depositario y un alguacil.

- Sanlúcar: Un factor, un asesor, un visitador de los navíos, un depositario, dos visitadores de fábricas y un arraez.

- Cádiz: Un factor y un alguacil.

- Puerto de Santa María: Un factor.

- Vélez-Málaga: Un factor.

- Motril: Un factor.

- Salobreña: Un alguacil y un guarda.

- Torrox: Un alguacil y un guarda.

- Almuñécar: Un alguacil y un guarda.

- Maro: Un alguacil y un guarda.

- Ayamonte: Un factor y un guarda.

- Puerto Real: Un alguacil.

- Palos: Un alguacil y un guarda.

- Moguer: Un alguacil y un guarda.

- San Juan del Puerto: Un alguacil y un guarda.

- Huelva: Un alguacil y un guarda.

- Aljaraque: Un alguacil y un guarda.

- Rincón: Un alguacil y un guarda.

- San Miguel: Un alguacil y un guarda.

- Cartaya: Un alguacil y un guarda.

- Redondela: Un alguacil y un guarda.

- Lepe: Un alguacil y un guarda.

- Gibraleón: Un factor.

- Marbella: Un factor.

Todos estos oficiales no sólo se ocupaban de inspeccionar los navíos y mercancias que llegaban a esos puertos y confiscar los de procedencia holandesa, si no que por Real Cédula de 19 de marzo de 1626 también podrían aprehender aquellos que hubieran sido producidos en Gran Bretaña ${ }^{76}$. Pero no sólo se ocuparían de vigilar los puertos, pues por Real Cédula de

76 Abreu Bertodano, J.A., op. cit., pág. 553. 
23 de abril de 1626, se ordenaba al Almirantazgo de Sevilla y a sus agentes que podían aprehender y confiscar todo tipo de mercancias y demás artículos de contrabando que hallaren en todas las ciudades, villas y lugares de Andalucía y del reino de Granada "de la tierra adentro" "7.

Al igual que los miembros de otras instituciones con jurisdicción propia, como los militares, los universitarios, los caballeros de las Ordenes Militares o los familiares de la Inquisición, entre otros, de los hechos ilicitos cometidos por los agentes del Almirantazgo conocerían el Almirantazgo de Sevilla y la Junta del Almirantazgo de Madrid, tal como se establecía en un Real Decreto de 19 de marzo de $1626^{78}$. Contra esta decisión protestó el Consejo de Castilla; sin embargo, el rey hizo caso omiso de las recomendaciones de dicho Consejo, ordenando que se cumpliera lo mandado con respecto al Almirantazgo, pero permitiendo que la jurisdicción ordinaria conociese «de oficio o a pedimiento de parte" de los delitos de lesa majestad, pecado nefando, homicidio, hurto y "todo género de resistencias a las justicias". También conocería la jurisdicción ordinaria de los delitos de «heridas, palos, palabras de injuria de las mayores, adulterios y estupros" cometidos por los oficiales del Almirantazgo, siempre que hubiere "parte interesada y por resolución de ella y no de otra manera" ${ }^{79}$. La respuesta dada al Consejo de Castilla se plasmó en la Real Cédula de 7 de noviembre de $1626^{80}$. Por un lado, se nombraba al licenciado Lucas de la Torre y al Doctor Alejandro de Montoya jueces; el primero, de la costa de Sanlúcar hasta Ayamonte y, el segundo, de la costa del reino de Granada. Las apelaciones contra las sentencias dictadas por estos jueces serían tramitadas por el Administrador y los jueces del Almirantazgo de Sevilla o por la Junta del Almirantazgo de Madrid, a elección del apelante. Los delitos cometidos por el Administrador y los jueces del Almirantazgo de Sevilla serían conocidos, en primera instancia, por la persona que nombrase a este propósito la Junta del Almirantazgo, siendo su decisión susceptible de ser apelada ante esa Junta.

\section{EL FIN DE LA FLOTA DEL ALMIRANTAZGO Y LA DECADENCIA DEL ALMIRANTAZGO DE SEVILLA}

Si la maquinaria del Almirantazgo en materia de control de puertos estaba tomando cuerpo como acabamos de ver, no sucedía lo mismo con la

ldem., pág. 556-557.

Consulta del Consejo de Castilla de 3 de abril de 1626, en A.H.N., Consejos, leg. 7134.

Idem.

B.N. 3/23124, pág. 79-84 
flota. Nunca se alcanzó la cifra de veinticuatro unidades previstas, sino que solamente dispuso de cuatro navíos y dos pataches ligeros para realizar las operaciones que tenia encomendadas ${ }^{81}$. Para tripular esta pequeña flota, se despachó desde Madrid una Real Cédula de fecha 5 de julio de 1625, en la que se concedía al Almirantazgo licencia para poder reclutar 500 infantes en tierras andaluzas.

Esta pequeña flota alcanzó algunos éxitos, pero después del ataque inglés a Cádiz en noviembre de 1625 se la ordenó que se uniera a la armada de don Francisco de Ribera, que fueran juntas a Lisboa y que allí diesen escolta a la flota de don Tomás de Larraspuru ${ }^{82}$. Estas labores duraron unos seis meses, tiempo durante el cual no pudieron realizar las misiones que originariamente tenían encomendadas de protección a los navíos mercantes y de lucha contra los holandeses en el mar.

Acabadas las ocupaciones con la Armada Real, dos desgraciados sucesos dieron lugar a que el Almirantazgo perdiese su flota. En primer lugar, la nave más importante de la flota se quemó y, en segundo lugar, algunos marinos de la nave capitana del Almirantazgo se amotinaron, mataron a su capitán, el flamenco Antonio Cool, apresaron a sus compañeros que no se habían unido a la rebelión y llevaron el navío con sus prisioneros a Holanda 83. No fue el único motín que se dio en los navíos de la flota del Almirantazgo. El 30 de mayo de 1626 se produjo otra deserción, esta vez de un navío de 32 piezas de artillería. Según un agente de Olivares, en un despacho dirigido a éste, toda la flota del Almirantazgo estaba a punto de amotinarse ${ }^{84}$.

La flota del Almirantazgo de Sevilla comenzaba a desvanecerse. En un intento de mejorar la situación, el 22 de septiembre de 1626 se promulgó una Real Cédula que prohibía, bajo pena de confiscación, todo tráfico de mercancías entre España y Flandes en navios que no fueran del Almirantazgo; muchos comerciantes protestaron contra esta medida y la eludieron enviando sus mercancías en barcos neutrales, especialmente franceses ${ }^{85}$. No sirvió de nada. El 5 de octubre de 1626 la Junta del Almirantazgo presentó a Felipe IV una petición en la que se solicitaba

B1 Asi se dice en la consulta de la Junta del Almirantazgo de 20 de mayo de 1628 (AG.S. Guerra y Marina, leg. 3152) y se reconoció en la Real Cédula de 24 de abril de 1625. (Servicio Histórico Militar (S.H.M), Depósito Histórico, libro 30, fol. 13).

82 Los gastos causados por esta operación fueron reclamados continuamente por la Junta del Almirantazgo. Asi, en la consulta de 12 de febrero de 1628 reclamaron al rey la suma de 3.408.708 maravedis que se les debia por esa operación (A.G.S., Guerra y Marina, leg. 3152).

83 Consulta de la Junta del Almirantazgo de 20 de mayor de 1628 (A.G.S., Guerra y Marina, leg. 3152).

84 A.G.S., Estado, leg. 2316, fol. 24-26.

85 Dominguez Ontiz, A., «Guerra económica...”, pág. 84-85 
que de una vez por todas se estableciese la tasa del 1\% para con ello aliviar la angustiosa situación de la flota del Almirantazgo, pero el rey demoró su respuesta con el pretexto de la celebración de las Cortes de Barcelona ${ }^{86}$. Ante la falta de contestación del monarca, el Almirantazgo de Sevilla presentó una nueva solicitud en fecha de 25 de mayo de 1627 , pero también obtuvo el silencio por respuesta ${ }^{87}$. El 31 de agosto de ese año, el Consulado de Sevilla escribía a Felipe IV dando cuenta que la flota del Almirantazgo sólo disponía de tres navíos, "con lo que puede temerse su ruina en la primera ocasión de importancia" ${ }^{88}$.

Al ser materialmente imposible la función naval prevista en la Real Cédula de 4 de agosto de 1624, el Almirantazgo sevillano se dedicará exclusivamente a la lucha del contrabando, tal como reconocia su Junta en la consulta de 20 de mayo de $1628^{89}$, y ello hizo que entrase en crisis. En 1630 los tres navios fueron desarmados $y$, años más tarde, la Junta del Almirantazgo, en una consulta presentada a Felipe IV de fecha de 16 de junio de 1633, estimaba que

"cesando el fin principal que se tuvo en el establecimiento del Almirantazgo, que fue el mantener en la mar una fuerza tan considerable como 24 navíos de guerra, assí para la ofensa de los enemigos de las Islas rebeldes como para asegurar el comercio con los Vasallos obedientes y los aliados del norte, no habia razón a los del Almirantazgo los privilegios y jurisdicción de que usan y el gozar de los descaminos de las mercaderias y demás cosas de contrabando, que por la cédula de su institución se les concedió" "90.

Por ello, junto a otras razones de índole económico, recomendó la Junta que el Almirantazgo de Sevilla

"que consta de cinco Jueces y el Asesor y otros muchos oficiales se reduzcan a sólo un Juez de ellos, que con el Asesor conozca y determine las causas del contrabando, reformando todos los demás oficiales que en los puertos de Sanlúcar, Cádiz, Gibraltar y Málaga y todos los demás de la costa se nombren Veedores y Subveedores en la forma que los hay en las otras provincias".

Felipe IV aceptó las conclusiones de la Junta del Almirantazgo y el 9 de septiembre de 1633 ordenó que al Juez que quedase y al Asesor se les

\footnotetext{
86 Inserta en la consulta de la Junta del Almirantazgo de 20 de mayo de 1628, (A.G.S., Guerra y Marina, leg. 3152)

8; Idem.

88 ARChivo General de Indias (A.G.I.), Indiferente General. leg. 755

89 A.G.S., Guerra y Marina, leg. 3152.

9 Idem. leg. 3160
} 
respetasen los mismos sueldos que antes gozaban y que ellos nombrasen los oficiales que creyesen pertinentes ${ }^{91}$. El Juez era Nicolás Antonio y el Asesor letrado fue don Antonio de Bolaños, Alcalde de Grados de Sevilla, siendo sustituído éste último por el licenciado don Juan de la Calle ${ }^{92}$. En 1637 murió Nicolás Antonio, quedando don Juan de la Calle como único responsable de los asuntos del Almirantazgo de Sevilla.

También los antiguos factores que estaban en los puertos de la costa andaluza fueron sustituídos por Veedores del Comercio y del Contrabando, agentes dependientes de la Junta y no del Almirantazgo de Sevilla ${ }^{93}$.

De esta forma terminó el Almirantazgo de Sevilla como organización de comerciantes flamencos y alemanes. A partir de entonces se convirtió en un simple tribunal especial dependiente no sólo judicial sino administrativamente de la Junta del Almirantazgo de Madrid, compuesto por oficiales nombrados por el rey.

\section{PRIMERAS ACTUACIONES DE LA REAL JUNTA DEL ALMIRANTAZGO}

Durante los tres primeros años de su existencia, la labor principal de la Junta del Almirantazgo fue el desarrollo normativo de los capitulos contenidos en las Reales Cédulas de 4 de octubre de 1624 y de 13 de enero de 1625 , sobre todo en lo relativo a la prevención y control de entrada de naves y mercancías holandesas y de otros enemigos de la Monarquía hispánica y la salida de todo aquello que estaba prohibido sacar conforme a las leyes. Entre esas normas destacan la Real Cédula de 6 de mayo de 1625, que ordenaba a los ministros de los puertos que se ayudasen de expertos en la construcción de navios para identificar navios holandeses ${ }^{94}$; la Real Cédula de 16 de septiembre de 1625, que prohibía subir a cualquier persona a los navios antes de que hubiera sido inspeccionado por los oficiales del Almirantazgo ${ }^{95}$; las tres Cédulas de 17 de febrero de 1626 dictadas en Barbastro, durante la celebración de las Cortes de Aragón, siendo el contenido de estas normas el siguiente:

\footnotetext{
91 Idem., leg. 3165.

92 Consulta de la Junta del Almirantazgo de 13 de octubre de 1634, en A.G.S., Guerra y Marina, leg. 3163.

${ }_{93}$ Consultas de la Junta del Almirantazgo de 9 de septiembre de 1633 (A.G.S., Guerra y Marina, leg. 3160 ) y de 8 de agosto de 1634 (A.G.S., Guerra y Marina, leg. 3163).

94 B.N., 3/23124, fol. 29

95 Abreu Bertodano, J.A., op. cit., pág. 509-510.
} 
1. Se ordena la obligación de todos los navíos que lleguen a los puertos andaluces que deberán empezar a descargar sus mercancias a los tres días de llegar al puerto y finalizar dicha descarga dentro de doce ${ }^{96}$.

2. Se permite que las mercancias confiscadas puedan ser objeto de venta antes que se dicte la sentencia de apelación. Dicha venta se haría "a estilo mercantil», sin que fuera sacada a pregón y pública almoneda ${ }^{97}$.

3. Se ordena que los capitanes y maestres de los navíos que salen de los puertos de Sevilla, Sanlúcar, Cádiz, Málaga, "y de los demás Puertos de aquel distrito", depositen una fianza de dos mil ducados, comprometiéndose a que proseguirán su viaje a su puerto de destino, perdiendo lo depositado en la fianza, "si surgieren al salir fuera de las Barras, y quedaren dando bordos de una parte a otra, veinte leguas de los dichos Puertos" ${ }^{98}$.

Por la Real Cédula de 28 de marzo de 1626, se dispone que todos los maestres de los navíos que arriben a los puertos del reino declaren las mercancias que traen, a quién vienen consignadas y las que llevan a otras partes, dando fianza de que, antes que vuelvan a salir, serán visitados por los oficiales del Almirantazgo ${ }^{99}$; la Real Cédula de 23 de abril de 1626 permite que el Almirantazgo y sus ministros puedan aprehender y confiscar todas aquellas mercancías traídas por contrabandistas halladas «tierra adentro en las Ciudades, Villas, y Lugares de Andalucía, y Reyno de Granada" ${ }^{100}$; Ia Real Cédula de 30 de julio de 1626, que ordena a los capitanes de navíos mercantes que arriban a los puertos bajo jurisdicción del Almirantazgo que traigan y exhiban el libro de sobordo, donde deben estar descritas las mercancías que transporta el barco, so pena del valor del quinto de las dichas mercancias en caso de no traer dicho libro, y de confiscación de todas, si no vienen reseñadas todas las mercancías que transporta 101; la Real Cédula de 19 de agosto de 1626, que modifica el régimen común en materia de ejecución de sentencias dadas en rebeldía, pudiéndose ejecutar las sentencias dictadas por el Almirantazgo de Sevilla en el plazo de dos meses desde la notificación, depositando el precio hasta que pase el año ${ }^{102}$; la Real Cédula de 7 de noviembre de 1626, que establece el régimen jurídico en materia penal que

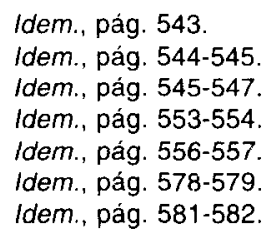


tienen los miembros del Almirantazgo 103; por último, la Real Cédula de 16 de enero de 1627, que ordenaba a los capitanes y maestres de los navíos que cargaban en los puertos del Almirantazgo mercancías españolas para transportarlas a otros puertos del extranjero, que deberían señalar el puerto de destino, depositar una fianza y traer los certificados que justificasen haber descargado esas mercancías en dicho puerto, operación esta última que deberian efectuar en el plazo de un año ${ }^{104}$.

La medida estipulada en esta última norma fue protestada. En carta de 17 de noviembre de ese mismo año, las repúblicas de Lübeck y Hamburgo se quejaban de los inconvenientes que suponían para su comercio las fianzas impuestas a los maestres de los navios ${ }^{105}$. Felipe IV dio marcha atrás con el tema de las fianzas.

Estas medidas tomadas por la Junta del Almirantazgo facilitaban la misión de inspección de sus agentes en la costa andaluza. Pero las actuaciones que realizaban los inspectores causaban graves perjuicios a comerciantes de naciones aliadas o neutrales, como polacos, hanseáticos y flamencos. Pese a estas protestas, Felipe IV ordenó reiteradamente que fuesen inspeccionados los navíos que llegaban a los puertos andaluces por los agentes del Almirantazgo. "Los resultados de los nuevos métodos -escribe J.I. Israel- fueron desde luego considerables. Si el embargo general tenía sólo un efecto temporal, los nuevos procedimientos de embarque, los almirantazgos y los tribunales comerciales transformaron definitivamente la situación en los puertos españoles. Las administraciones locales de Sevilla, Sanlúcar, Málaga y otras ciudades protestaron reiteradamente de que su comercio iba a arruinarse, pero la corona no se inmutó. Los ministros de Felipe IV preferian sufrir pérdidas en tráfico e ingresos comerciales si con ello podían perjudicar a los holandeses" ${ }^{106 .}$

Pero las quejas contra la actuación del Almirantazgo llovían constantemente al rey. En fecha de 31 de agosto de 1627, el Consulado de Sevilla se quejaba del comportamiento de los agentes del Almirantazgo y de los daños que causaban a los navíos extranjeros, so pretexto de ver si traían mercancias de rebeldes, que por ello acabarían por ahuyentar a los comerciantes extranjeros de los puertos españoles y, por consiguiente, causarían la ruina del comercio americano.

103 B.N., 3/23124, fol. 79-84

104 Agreu Bertodano, J.A., op. cit, vol. IV, 1743, pág. 10-12.

105 A.G.S., Estado, leg. 2328, fol. 173.

to6 ISRAEL, J.I., “Un conflicto entre imperios: España y los Países Bajos», en ELLIOTT, J.H.: Poder y sociedad en la España de los Austrias, Barcelona, 1982, pág. 167. 
«Es considerable el modo con que el Almirantazgo — dice la carta- se ha cautelado en perjuicio del comercio y en aumentos propios. Dice el testimonio de haberse entregado las mercaderías sean dentro de un año de como acá se despacharon y de lo contrario el fiador pague el principal de ellas de suerte que la transacción del año, sin otra averiguación ni probanza sirva de sentencia de remate... y siendo tan contingente perderse en alta mar un navio con todas las mercaderias donde no hay a quien pedir testimonio, vendrán los pobres fiadores a padecer los daños el desembolso y la pérdida de las mercaderías" ${ }^{107}$.

No sólo el Consulado se quejaba, el Consejo de Hacienda apoyó las demandas del Prior y de los Cónsules sevillanos. La exigencia del Almirantazgo de que todo el que embarcase mercancías hubiese de señalar el punto a donde se dirigían, obligándose a traer certificados del lugar donde los desembarcaran, como establecía la Real Cédula de 16 de enero de 1627, creía el Consejo de Hacienda que «más servía de extorsión y vejaciones a los mercaderes de frutos del Reino para fuera del que de prevención que se lleven a tierras obedientes y amigos de esta Corona". Aducia la pérdida que habian tenido los arrendadores de los derechos de lanas y salinas de Andalucia, porque muchos dejaban de cargar, sin que por ello pudiera asegurarse que se cumplía la finalidad perseguida, porque desde un país amigo se podían llevar los géneros a otro enemigo ${ }^{108 .}$

Pero las actuaciones del Almirantazgo no sólo eran criticadas por el Consulado de Sevilla y por el Consejo de Hacienda. El conde de Solre, enviado a Varsovia para comprar navíos polacos con el objeto de reforzar la armada de Flandes, envió a Felipe IV una memoria sobre los daños y quejas de las actuaciones de los agentes del Almirantazgo a comerciantes y marinos polacos y hariseáticos ${ }^{109}$. La Junta del Almirantazgo respondió a cada una de esas quejas en consulta de 8 de mayo de 1628, aclarando que solamente sus oficiales habian aplicado las normas vigentes en materia de contrabando y nunca se habian extralimitado en sus funciones ${ }^{110}$. En una de esas quejas se acusaba a los agentes del Almirantazgo haber dado tormento a los oficiales de un navío polaco para que confesasen que dicho buque se habia fabricado en Holanda, "y que fue condenado y que no han querido vender el navio ni recibir fianzas con codicia de tenerlo para sí y que estiman este daño en 20.000 ducados». El Almirantazgo de Sevilia, a instancia de la Junta, respondió que la relación que se hacía de este caso era falsa, porque para averiguar la verdad

107 A.G.I, Indiferente General, leg. 755.

108 A.G.S., Consejo y Juntas de Hacienda, leg. 632.

tog Consulta de la Junta del Almirantazgo de 11 de enero de 1628, en A.G.S., Guerra y Marina, leg. 3152 .

110 A.G.S., Guerra y Marina, leg. 3152 
no se utilizó tormento, sino que sirvió la declaración de los cómplices en la comisión del delito; que ese navio se remató en 8.000 ducados de plata; que el comprador del barco lo envió a Italia con su antiguo Maestre y que el rey de Polonia no era su propietario, sino que los interesados se valian de pasaportes de ese Estado para conseguir sus ilícitos fines.

No sólo la Junta del Almirantazgo tuvo que responder a protestas de actuaciones realizadas por sus oficiales. La propia Junta también se quejaba de actuaciones de otros órganos estatales contra sus agentes. A principios de 1626, el conde de la Puebla, Presidente de la Casa de la Contratación y Administrador General de los Almojarifazgos, permitió que sus oficiales cobrasen derechos a los funcionarios del Almirantazgo que estaban comprando pertrechos y armamentos para la flota. La Junta del Almirantazgo protestó contra esta ilegalidad y rogó al monarca que promulgara una Real Cédula dirigida al conde de la Puebla, en la cual se insertase el capítulo 8 de la Real Cédula de 4 de octubre de 1624 y le ordenase que en el futuro no cobrara a los agentes del Almirantazgo ningún tipo de derecho. Felipe IV promulgó la norma el 14 de julio de $1626^{111}$.

Temiendo posibles conflictos con la Inquisición, pues estaba encargada de vigilar en los puertos la entrada de libros y obras heréticas $y$, desde el 24 de marzo de 1627, impedir la entrada de moneda de vellón falsa ${ }^{112}$, se solicitó al Inquisidor General, don Andrés Pacheco, que informara a los comisarios del Santo Oficio situados en los puertos andaluces sobre la creación del Almirantazgo y de sus funciones inspectoras. El 8 de septiembre de 1626 escribió el Inquisidor General a los comisarios referidos ordenándoles que efectuaran las visitas de los navios junto a los agentes del Almirantazgo y tuvieran buena relación con ellos ${ }^{113}$.

\section{LA REFORMA DE 1628: LA EXPANSIÓN TERRITORIAL DE LA JURISDICCIÓN DE LA REAL JUNTA DEL ALMIRANTAZGO}

\section{A. La Real Cédula de 16 de mayo de 1628}

Aunque el Real Decreto de 10 de febrero de $1625^{114}$ habia ordenado que la Junta de Comercio remitiera a la recién creada Junta del Almiran-

B.N., 3/23124, fol. $69-70$.

Dominguez Ortiz, A., Política y Hacienda de Felipe IV, 2. ${ }^{a}$ ed., Madrid, 1983, pág. 242.

A.G.S., Guerra y Marina, leg. 3152.

A.G..S., Estado, leg. 2847. 
tazgo todos los papeles referentes al contrabando holandés, todavía proseguía en sus funciones. En abril de 1625 propuso la Junta de Comercio a Felipe IV

«la forma en que se habia de tener en la guarda de los puertos y la conveniencia que de ello se seguiría y de instituir en todos los del Reino un libro de registros y manifestaciones donde se registrasen las mercaderías extranjeras y se tuviese cuidado de obligar a los dueños y factores que en retorno de ellas llevasen otras de la tierra del término contenido en la ley que sobre esto se promulgó en veinte y ocho de febrero de seiscientos y veinte y seis" ${ }^{115}$.

El 1 de mayo de 1625 Felipe IV remitió a la Junta del Almirantazgo lo acordado por la de Comercio y diera su parecer. La Junta del Almirantazgo, en consulta de 31 de marzo de 1626 , dio su visto bueno al proyecto realizado por la Junta de Comercio, estableciendo la forma en que se debía ejecutar y proponiendo personas al rey para que vigilasen los puertos ${ }^{116}$.

Lo decidido en la Junta del Almirantazgo fue a su vez objeto de estudio por una Junta "ad hoc» formada por Fr. Iñigo de Brizuela, Presidente de la Junta del Almirantazgo; el marqués de Montesclaros, Presidente de la Junta de Comercio; don Juan de Villela; el marqués de la Hinojosa y don Juan de Pedroso. Después de varias reuniones la Junta aprobó, en consulta de 25 de marzo de 1627, lo hecho por las Juntas del Almirantazgo y del Comercio un año antes. Felipe IV, en el Decreto marginal de esta consulta, acordó extender la jurisdicción de la Junta del Almirantazgo (nótese que dice "Junta del Almirantazgo" y no "Almirantazgo") a todos sus dominios europeos para luchar contra el comercio de los holandeses y demás enemigos de la Monarquía hispánica ${ }^{117}$.

Ante esa resolución del monarca, pronto se presentaron protestas. El 21 de diciembre de ese mismo año se presentó al rey un memorial en el que se afirmaba que la riqueza del reino se basaba en la libertad de comercio con otros Estados ${ }^{118}$. Pero respetar la libertad de comercio no era el objetivo de Felipe IV, sino derrotar de cualquier forma a los enemigos de la Monarquia hispánica.

La Junta del Almirantazgo, en consulta de $1 .^{\circ}$ de mayo de 1628 , aprobó lo contenido en la de 25 de marzo de 1627, disponiendo que la Real

15 A.G.S., Guerra y Marina, leg. 3152.
Idem.
17 Idem.
18 GONZALEZ DE SALCEDO, P., Tratado juridico-político del Contrabando, $3 .^{{ }^{\circledR}}$ ed., Madrid, 1729 , pág. 24-25. 
Cédula de prohibición de comercio se enviase previamente al Consejo de Estado, para que esta institución la promulgase y la publicase. También censuraba la Junta del Almirantazgo la tardanza en haberse tomado esta decisión y, sobre todo, que hubieran intervenido otras instituciones distintas a ella. Por último, la Junta del Almirantazgo solicitaba al rey que una vez refrendada la Cédula por un Secretario del Consejo de Estado o de la Cámara, todos los demás despachos hechos en ejecución de esa norma serian refrendados por la propia Junta ${ }^{119}$.

El 16 de mayo de 1628 se promulgó la Real Cédula de prohibición de comercio ${ }^{120}$. De su "exposición de motivos" se desprende que su objetivo era evitar los fraudes que se han utilizado para introducir mercancias "con aplicar su fábrica a otras Provincias obedientes, y confederadas". La Real Cédula de 16 de mayo de 1628 supone una resurrección de parte del plan de Juan de Gauna de principios del siglo XVII: establecer medios de control en los puertos de entrada y de salida de mercancias de Flandes y de España, para impedir la entrada de productos holandeses ${ }^{121}$.

La Real Cédula consta de nueve capítulos. En primer lugar se declaran vigentes todas las normas anteriores que se habian dictado para combatir el comercio ilícito que practicaban los holandeses y sus aliados, especialmente los ingleses ${ }^{122}$.

Seguidamente se establecen las prohibiciones ${ }^{123}$ :

1. Las personas "de los rebeldes, y enemigos que vinieren a estos Reynos, o llegaren a sus puertos, o desembarcaren en ellos".

2. Los navíos «que fueren de las tales personas o vinieren por su cuenta", asi como los construídos en los astilleros de las Provincias Unidas.

3. Las mercancías que transporten dichos navios, "ya fueran propias o ajenas, fueran por su cuenta o por la de terceros".

4. Los navíos que traigan mercancias que están prohibidas comerciar en los territorios de la Monarquia hispánica, si se probase realmente que los dueños o los capitanes de los buques tenían conocimiento de que eran mercancias consideradas ilícitas.

119 A.G.S., Guerra y Marina, leg. 3152.

120 Idem; también se encuentra publicada en Gonzalez DE SALCEDO, P., op. cit., pág. 28-36.

121 Sobre el plan de Juan de Gauna, ECHEVARRía BACigaluPE, M.A., "Un notable episodio en la guerra económica hispano-holandesa: el Decreto Gauna (1603)», Hispania, 46 (1986), pág. 57-97.

122 Cap. 1

123 Cap. 2. 
5. Las mercancías de tierras con quien está permitido el comercio traídas a los dominios del rey de España, "si habiendo tocado en los puertos de los dichos rebeldes y enemigos", les pagasen un tributo.

También se establecían las medidas contra los que contravinieren lo establecido en la Real Cédula. Los rebeldes y demás enemigos de la Monarquía hispánica deberían ser apresados donde fuesen encontrados y las mercancías serian confiscadas y convertidas en dinero, debiéndose dividir el precio en cuatro partes, distinguiendo si en el lugar hay o no Capitán General ${ }^{124}$. Si hay Capitán General:

- $1 / 4$ para la Hacienda Real

- $1 / 4$ para el Capitán General.

- $1 / 4$ para el denunciante.

- $1 / 4$ para pagar "los gastos que se hicieren en las Veedurías generales de los Reinos, y lo demás en cumplimiento de esta Cédula se ha de ejecutar".

En los lugares donde no exista Capitán General, las confiscaciones se repartirán:

$-1 / 4$ para la Hacienda Real

$-1 / 4$ para el denunciante.

- $1 / 4$ para pagar «los dichos gastos". Si no hubiese bastante dinero para pagar estos gastos, "se suplirá (de lo que corresponde a la Hacienda Real) lo que faltare para pagar las costas, y gastos referidos".

Para prevenir fraudes cometidos por los denunciantes, se dispone que éstos no deben realizar convenios ni con las partes ni con otras personas para repartirse el fruto de lo obtenido en la confiscación, pues en caso contrario perderían su parte junto con otro tanto.

Finalmente dispone el capítulo 2 que en la causa de contrabando que haya sido iniciada de oficio, se debía nombrar un Fiscal, si se considerase necesario, y la parte correspondiente al denunciante sería destinada a la Hacienda Real.

Debían conocer de las causas de contrabando las personas nombradas por el rey en los lugares que se determinase, prohibiendo a otros oficiales reales conocer de estos asuntos y ordenándoles, además, que remitiesen

124 Consulta de la Junta del Almirantazgo de 5 de abril de 1628, A.G.S., Guerra y Marina, leg. 3152 
a los ministros nombrados por el monarca las causas que ya hubieran comenzado. En el caso de no haber ministro real del contrabando, conocerían las justicias ordinarias del lugar. De las resoluciones judiciales dictadas por los ministros del contrabando (conocidos más tarde como Veedores del Comercio y del Contrabando) como por las justicias ordinarias, serían recurribles en grado de apelación ante la Junta del Almirantazgo ${ }^{125}$. A partir de entonces, "el Almirantazgo de Sevilla se eclipsó; la Junta suprema de Madrid, que empezó a llamarse Junta del Contrabando, cubrió con una red de agentes no sólo, como al principio, el litoral sur, sino todas las costas de la Peninsula» ${ }^{126 .}$

Después de declarar la competencia de los ministros del contrabando y de la Junta, se establecian las mercancías consideradas prohibidas. Encabezaban la lista los productos textiles, siguiendo a continuación una gran multitud de artículos suntuarios o de uso corriente, como muebles, relojes, libros, pinturas, peines, etc. ${ }^{127}$. En palabras de Domínguez Ortíz, demuestra esto "un claro testimonio del fallo impresionante de la industria española” ${ }^{128}$.

El capítulo 5 supone una novedad en el panorama jurídico de la lucha contra el comercio ilícito holandés. Se dispone en este capítulo que todas las mercancias que se traigan de las provincias flamencas sometidas a la autoridad de Felipe IV, así como de las ciudades hanseáticas o de otras "partes del Septentrión", deben llevar certificados despachados por agentes del rey de España establecidos en aquellos lugares y dirigidos a los ministros encargados de combatir el contrabando. A los comerciantes que no llevasen consigo esos certificados o que no los presentasen, se les confiscarian las mercancias y los navios que las transportaren. También se confiscarian las mercancías consideradas jurídicamente lícitas que vinieran junto con las ilícitas, las procedentes de Inglaterra, aunque hayan sido compradas previamente en Flandes o de otros territorios aliados o confederados del rey de España y todas las especias y demás mercancias procedentes de las Indias Orientales que no lleven registro de la Casa da India o de la Real Alfondiga portuguesa. Por último, se ordena la persecución de los introductores de moneda falsa.

Los maestres y patrones de los navíos, una vez que llegaban a los puertos hispanos, debían entregar la documentación de las mercancias

\footnotetext{
Cap. 3.

Dominguez ORtiz, A., "Guerra económica...", pág. 90.

Cap. 4.

128 Dominguez Ortz., A., "Guerra económica...", pág. 91
} 
que llevasen a bordo a los agentes del contrabando y, en los puertos secos, serian los administradores de las aduanas los encargados de realizar esa fiscalización. Todas las mercancias que se hallasen fuera de registro o que no se hubieran declarado serían confiscadas ${ }^{129}$.

Se atribuia a los agentes de la Junta del Almirantazgo la facultad de vigilar el cumplimiento de lo establecido acerca de la obligación de pagar las mercancías importadas en frutos del reino y no en moneda. Para ello disponían de un libro donde asentarian las mercancías que llegasen y saliesen de los puertos, ordenando que no fueran admitidas mercancías sin que sus dueños hubiesen depositado previamente fianzas, garantizando asi el cumplimiento de la ley ${ }^{130}$.

La prohibición de comercio sólo se limitaba a los holandeses y demás enemigos de España, pero se permitía el libre comercio de todos aquellos reinos y repúblicas con los dominios del rey de España y viceversa, excepto con las Indias Orientales y Occidentales ${ }^{131}$.

Finalmente, se disponía que la Junta del Almirantazgo era el único órgano competente para poner en ejecución lo contenido en la Real Cédula de 16 de mayo de 1628, inhibiendo al resto de las autoridades judiciales españolas del conocimiento de las causas de contrabando, siendo la Junta del Almirantazgo el único órgano judicial al que deberían acudir los recursos de apelación de las sentencias dictadas tanto por los oficiales del contrabando como por las justicias ordinarias del lugar, y siendo el ámbito territorial de aplicación no solamente los reinos y señoríos que componen la Corona de Castilla, sino también las Coronas de Aragón y Portugal, las Provincias Obedientes de Flandes y los dominios italianos de Nápoles, Sicilia y Milán ${ }^{132}$.

\section{B. La Instrucción para los Veedores del Comercio y del Contrabando.}

Junto a la Real Cédula de 16 de mayo de 1628, se promulgó una Instrucción mediante la cual se daban las indicaciones que debían seguir los agentes de la Junta encargados de la lucha contra el contrabando, los Veedores del Comercio y del Contrabando ${ }^{133}$.

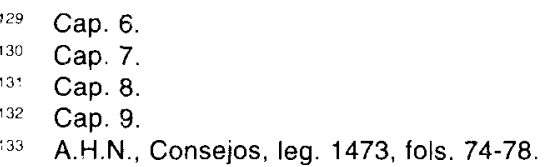


La Instrucción está dividida en dieciocho capítulos. En el primero de ellos se establecen cuáles son los objetivos que deben perseguir los Veedores: conseguir que los holandeses y demás enemigos del rey de España no comercien en la Península Ibérica ni saquen beneficios de ese comercio.

En el segundo capítulo se ordenaba a los Veedores del Comercio y del Contrabando que enseñasen su nombramiento a las autoridades locales y que lo mandasen publicar. El Veedor tendría un puesto en la aduana, donde debería llevar un libro en el que se tomaría asiento de las mercancías que entrasen y saliesen de la zona bajo su jurisdicción. El personal de aduanas no podria despachar ninguna mercancía sin que previamente hubiera sido inspeccionada por el Veedor. Por último, no se admitirian en los puertos la descarga de los navios que no hubieran sido visitados por el Veedor o por la persona que le sustituyese, estudiando el contenido de los libros de sobordo, las cartas de fletamento o registro.

El capítulo 3 de la Instrucción desarrolla el capítulo 5 de la Real Cédula de 16 de mayo de 1628, estableciendo que las personas que tuvieran que registrar en Flandes 0 en otras partes todas las mercancías con destino a España, debían mantener correspondencia, no sólo con el Veedor del Comercio y del Contrabando, sino también con el Secretario de la Junta del Almirantazgo, a quien vendrían los avisos de navíos y mercancías con destino a España. El Secretario de la Junta, a su vez, debería informar al Veedor de todo lo que considerase necesario para que éste realizase de la mejor forma posible su labor.

El capítulo 4 es uno de los más importantes de la Instrucción pues en él se regula y se establece cómo los Veedores deben realizar la visita a los navíos. En primer lugar, cuando el navío llegase al puerto, el Veedor debería ser el primero en subir a bordo y no otra persona, para de esa forma evitar fraudes. Si llegasen dos o más navíos, se pondrían guardas en cada uno de ellos hasta que se acabara la visita.

Una vez en el barco, el Veedor del Comercio y del Contrabando ordenaria al maestre que le entregase el libro de sobordo, el registro o cargazón de las mercancías que trajese, con sus marcas y declaraciones de los dueños o de sus factores a quien vinieran consignadas. En segundo lugar, deberia aportar el registro o pasaporte que le hubiera sido entregado por la persona nombrada por el rey en Flandes o en otras partes. Seguidamente se apercibiria al maestre que dijese qué mercancías venían fuera de registro y sí traía mercancías consideradas ilícitas. Finalmente, si se sospechase que el navío ha sido construido en astilleros holandeses, se tomaría declaración al maestre y a los miembros de la tripulación o del pasaje que se consideraran necesarios. 
Una de las formas que tenían los holandeses y los demás contrabandistas de sacar metales preciosos y mercancias vedadas de España era que una vez que sus navíos salían de los puertos hispanos y se perdían de vista, esperaban a que anocheciera para volver a la costa y luego las cargaban. Otro tipo de fraude que se cometía era que los navios descargaban fuera de los puertos o por la noche parte de las mercancias. Para prevenir estos fraudes, el capitulo 5 establecía que, en el primer caso, los maestres de los navíos tenían la obligación de proseguir su viaje hasta el puerto de destino que figurase en sus documentos, sin detenerse en otros lugares, salvo por motivos de fuerza mayor; en caso contrario se les impondría una pena de dos mil ducados y se procedería judicialmente contra el maestre si se descubriesen en el navio mercancias de contrabando. Para su averiguación, en el momento de la partida del navío, el Veedor ordenaba que tres personas reconocieran el navío por dentro y una vez terminada su labor, bajaran a tierra y esperaran a que el navío se perdiese de vista. En el segundo caso de fraude. el Veedor haria declarar al maestre del navio las mercancías que traía, a quién venian consignadas en aquel puerto y si llevaba otras para otros lugares, mostrando los documentos que lo certificaran y obligándose, bajo pena de dos mil ducados, a que antes de que el navío saliese del puerto, sería objeto de una visita para averiguar si todavía llevaba las mercancias con destino a otros lugares. En el caso de que esas mercancías se hubiesen descargado antes de haber realizado la inspección, serían susceptibles de ser confiscadas, lo mismo que si hubiera cargado otras mercancias y no las hubiera registrado. Por último, se concedía un plazo de quince dias a los dueños de los navíos para efectuar la descarga de las mercancías, con la facultad de prorrogar ese plazo de tiempo. En el caso de haber pasado esos quince dias o la prórroga concedida, las mercancias serian descargadas por orden del Veedor, corriendo los gastos por cuenta del propietario del navio.

En el capítulo 6, reconociéndose la complicidad de algunos barqueros de los puertos en los fraudes que se cometen, se les prohibe salir sin ser previamente visitados y sin licencia del Veedor del Comercio y del Contrabando, cuando entren o salgan navíos del puerto.

El capítulo 7 señala quiénes son las personas encargadas tanto en Flandes como en las ciudades hanseáticas de dar los certificados a los mercaderes para que puedan entrar en España las mercancías que se establecen en la Real Cédula de 16 de mayo de 1628. Estas personas son, Hortuño de Urizar, residente en Flandes, y, el flamenco Gabriel de Roy, establecido en las ciudades de la Hansa. alemana.

Los certificados y registros traídos por los maestres de los navíos y por los comerciantes a los Veedores del Comercio y del Contrabando deberían 
ser enviados al Secretario de la Junta del Almirantazgo, dejando copia de los certificados y registros en un libro encuadernado dedicado para ello. La finalidad de la medida era confrontar los documentos que se habían recibido en los puertos con los enviados por Hortuño de Urizar o por Gabriel de Roy o por sus representantes o sucesores ${ }^{134}$. El asiento hecho en el libro mencionado debería ser firmado por el Veedor del Comercio y del Contrabando y por el maestre del navio o por la persona que hubiera entregado esos documentos, y siempre en presencia de un escribano ${ }^{135}$.

Si los certificados y registros eran falsos, el capítulo 10 ordenaba que se tasaran las mercancias, ordenando a la persona o personas a quien venian consignadas que dieran fianzas de acuerdo a su valor de tasación y que en el plazo de ocho meses presentaran certificados de las personas encargadas de darlos. Si no lo trajesen, se cobraría la fianza, lo mismo que si el certificado presentado no confrontaba con el que tenía en su poder el Secretario de la Junta.

A los comerciantes franceses considera la Instrucción como los mayores burladores de las normas de prohibición de comercio con los rebeldes holandeses, pues ellos, incumpliendo los tratados suscritos entre España y Francia, llevan mercancías españolas a las Provincias Unidas. Por ello, el capítulo 11 ordena a los Veedores que valiéndose de los medios que consideren convenientes, se informen del paradero de las mercancías transportadas por los comerciantes franceses; uno de esos medios, dice la Instrucción, puede ser la utilización de espías situados tanto en España como en otros lugares del extranjero. Si esos espias descubriesen que los holandeses mantienen comercio y bienes encubiertos en España, se debe dar cuenta de ello a la Junta del Almirantazgo para que de la solución que estime adecuada y los Veedores deberán realizar las diligencias necesarias para acabar con ese comercio y aprehender los bienes ${ }^{136}$.

El Veedor del Comercio y del Contrabando tenía la jurisdicción civil y criminal que anteriormente había correspondido al Almirantazgo de Sevilla, pudiendo condenar o absolver a todas las personas inmersas en las llamadas "causas del contrabando", siendo sus decisiones apelables ante la Junta del Almirantazgo de Madrid. En el caso de dictar sentencia condenatoria, la ejecución y reparto de los bienes sería realizado en la forma prevista en la Real Cédula de 16 de mayo de 1628, aunque no se daria al denunciante su parte hasta que no fuera la sentencia confirmada por la

134 Cap. 8.

135 Cap. 12.

136 Cap. 13. 
Junta en grado de apelación. Por último se concede al Veedor del Comercio y del Contrabando la facultad de poder nombrar receptores ${ }^{137}$.

Para prevenir acuerdos fraudulentos entre los Veedores y los denunciantes de contrabando con el objeto de repartirse la parte que les corresponde de los bienes aprehendidos, dispone el capítulo 16 de la Instrucción que no debían admitir denuncias de criados o de allegados de los Veedores, ni que realicen éstos convenios con los denunciantes, pues en caso contrario se penalizaría al denunciante con la pérdida de la cuarta parte de los bienes confiscados que le correspondía y al Veedor se le impondría una multa cuyo valor es esa cuarta parte a la que se le sumaría el $4 \%$ de esa cantidad. También se prohibe a los Veedores realizar contratos y negocios con los comerciantes ${ }^{138}$.

El capítulo 17 declara que ningún Tribunal ni Consejo puede dar permiso para dejar entrar mercancias prohibidas o navegar hacia las Provincias Unidas, aunque ese permiso estuviera firmado por el rey. Por ello, se dice en la Instrucción «estaréis advertido de sobreseer su cumplimiento, siempre que las cosas de esta calidad llegaren a vuestra noticia, si fuere en vuestra jurisdicción: $y$ donde no alcanzare procuraréis embargarle, hasta dar cuenta en la Junta, y que se ordene por ella, lo que conviniere executarse".

Por último, se ordena a los Veedores del Comercio y del Contrabando que traten a los comerciantes extranjeros de buenas maneras en los puertos españoles, tanto a la entrada como a la salida, y que no lleven ningún tipo de derecho o tasa cuando dieren algún despacho sobre las mercancías que entraran y salieran de los puertos de sus respectivos distritos ${ }^{139}$.

\section{Los cambios en la Junta: Brizuela-Leganés, Carnero-Gómez de Lasprilla}

Con la Real Cédula de 16 de mayo de 1628 la jurisdicción de la Junta del Almirantazgo se extendió a todos los dominios peninsulares de Felipe IV. Los Veedores del Comercio y del Contrabando fueron instalados en los principales puertos españoles, puertos en los que ya realizaban sus funciones los comisarios de la Inquisición y los agentes del Consejo de Guerra. Muy pronto, los Veedores de Vizcaya, Guipúzcoa y Cartagena tuvieron

\footnotetext{
Cap. 15

Cap. 18.

Cap. 14.
} 
conflictos con los comisarios de la Inquisición. Por ello, la Junta del Almirantazgo, en consulta de 4 de septiembre de 1628 , solicitó al rey que los comisarios del Santo Oficio de esos lugares colaboraran como se habia ordenado a los de Andalucía en $1625^{140}$. A ello accedió Felipe IV e informó al Inquisidor General, el cardenal Zapata. Pero ese mismo año, en San Sebastián se produjo un conflicto entre el comisario inquisitorial y el Veedor Francisco Retama. Éste amenazó con prender a los oficiales de la Inquisición cuando se encontraban a bordo de un navio, en virtud de las órdenes recibidas ${ }^{141}$. Conflictos similares sostuvo la Junta del Almirantazgo con el Consejo de Guerra. En una consulta de 18 de octubre de 1628 solicitó al rey que diera una orden especial en la cual se estableciera que fuera la Junta del Almirantazgo y no el Consejo de Guerra el tribunal competente para conocer en grado de apelación de unas causas de contrabando que habian llegado al Consejo, pues conforme a la Real Cédula de 16 de mayo de ese año, el Consejo debía inhibirse de su conocimiento y mandar todas las actuaciones a la Junta, como era preceptivo ${ }^{142}$.

A finales de 1628 se produjeron cambios en la Junta del Almirantazgo. Debido a su edad y a su salud, Fr. Iñigo de Brizuela solicitó a Felipe IV el retiro de todas sus ocupaciones. Brizuela falleció al poco tiempo en Madrid. El rey accedió a sus deseos y por un Real Decreto expedido en el El Escorial el 21 de octubre de 1628 nombró como Presidente del Consejo de Flandes a don Diego Mexía de Guzmán, marqués de Leganés y primo del conde duque de Olivares ${ }^{143}$. El mismo día, Felipe IV expidió otro Real Decreto en el que nombraba Presidente de la Junta del Almirantazgo a don Fernando Girón ${ }^{144}$. Sin embargo, éste aceptó el cargo, alegando que sus ocupaciones le impedían atender con la eficacia debida la Presidencia de la Junta. Fue el marqués de Leganés, el sustituto de Brizuela en el Consejo de Flandes, quien de forma transitoria ocuparía este cargo, que desempeñaría hasta la disolución de la Junta en 1643, tal como se disponía en el Real Decreto de 8 de diciembre de $1628^{145}$.

No sólo se produjeron cambios en la dirección de la Junta. Antonio Carnero, Secretario de la Junta del Almirantazgo, fue nombrado Secretario

140 A.G.S., Guerra y Marina, leg. 3152.

14. Pérez de Colosia, M.I. y Gil Sanjuan, J., "Inspección inquisitorial a los navíos y control de libros", Jabega, 25 (1979), pág. 29.

142 A.G.S., Guerra y Marina, leg. 3152

143 Rabasco Valdés, J.M., El Real y Supremo Consejo de Flandes y de Borgoña (1419-1702), tesís doctoral inédita leida en la Universidad de Granada en 1981, pág. 255.

${ }^{144}$ Real Decreto de 21 de octubre de 1628, A.G.S., Guerra y Marina, leg. 3152

${ }^{145}$ A.G.S., Guerra y Marina, leg. 3152. 
del Consejo de las Ordenes Militares el 5 de octubre de $1628^{146}$. Por ello, fue sustituido en su puesto en la Junta del Almirantazgo por el Secretario Francisco Gómez de Lasprilla, Secretario de Su Majestad "ad honorem" desde el 6 de noviembre de $1624^{147}$. Mediante Real Decreto de 18 de octubre de $1628^{148}$, refrendado por la Real Cédula de 9 de noviembre de ese mismo año ${ }^{149}$, Francisco Gómez de Lasprilla ocupó su cargo de Secretario de la Junta del Almirantazgo, cargo que ocuparia hasta 1630.

146 Escudero, J.A., Los Secretarios de Estado y del Despacho, vol. I, Madrid, 1976, pág. 249.

167 A.G.S., Quitaciones de Corte, leg. 17.

148 A.G.S., Guerra y Marina, leg. 3152.

149 S.H.M., Depósito Histórico, lib. 30, fols. 128-129. 